\title{
SYSTEMIC COMPONENTS OF ECONOMIC SECURITY OF HIGHER EDUCATION INSTITUTION
}

\author{
Olena Zhukova ${ }^{1}$, Volodymyr Parsyak ${ }^{2}$
}

\begin{abstract}
The purpose of the paper is to search for arguments to confirm the working hypothesis about the importance of implementing a systemic approach to using the effective means of ensuring economic security of higher education institutions in terms of their further involvement in market relations. It is necessary to adapt the universal concept of a systemic approach to the peculiarities of the participants' relations in the educational process. Methodology. To solve the problems arising from the purpose of the study, methods of generalization and systematization of primary information obtained during the observation of the practice of domestic higher education centers, as well as data from state statistics have been used. Results. Modern centers of educational services are going through a period of profound transformation. Along with the strengthening of business requirements for the quality of intellectual capital they produce, the competitive confrontation with Ukrainian and, more recently, foreign providers of educational services has significantly intensified. Moreover, the relevant state policy has changed dramatically, accordingly, it is becoming increasingly difficult to rely on budget funding, and the economic security is becoming a daily affair of the whole academic management. Taking care of the future wellbeing is becoming a matter for everyone: from the rector to the head of the department, even professors and senior lecturers. The scientific work has examples of how this problem is solved in relations with key stakeholders: applicants, educational institutions operating in common market segments, representatives of the business community, state executive authorities. The subject of special attention is the internal system structure, the important characteristics of which are considered to be flexibility, balance, and economy. For this reason, it is proposed to distinguish key activities of the educational institution: operating, research and development of the institution and administration. The vectors for development are determined: digitalization, personalization of education, project approach to the formation of educational content, a combination of its formal and informal forms.
\end{abstract}

Key words: economics, economic security, educational services, educational institutions, system, structure, relations, academic management.

JEL Classification: A10, 123, 125

\section{Introduction}

We have demonstrated our commitment to a systemic approach (Parsiak, Drahomyrova, 2010; Dybach, Zhukova, Parsiak, 2019), the direction of the methodology of cognition, which moves the initiators of scientific research. We will not betray this approach in the future because it establishes the foundation for design of facilities with a complex internal organization. Higher education institutions (HEIs) occupy a prominent place among them. The reflection of reality through a systemic approach involves a movement towards truth making the solution of some interrelated problems. The first of them is the use of the inherent object of the conceptual and categorical apparatus. To this end, it is desirable:

a) to define the system as a relatively autonomous set of interconnected elements capable of self-diagnosis, self-assessment, self-adjustment, self-development and continuous exchange of information with each other and environment;

b) to find dialectical or genuine antagonisms between order of the system elements and disorder, which not only continues to exist in spite of all the efforts of management and dedicated employees, but has the ability to neglect the subordination of elements to each other and to the system in general. Observations show

\footnotetext{
Corresponding author:

${ }^{1}$ Admiral Makarov National University of Shipbuilding, Ukraine.

E-mail: eyzhukova@gmail.com

ORCID: https://orcid.org/0000-0001-8966-8354

${ }^{2}$ Admiral Makarov National University of Shipbuilding, Ukraine.

E-mail: volodymyr.parsyak@nuos.edu.ua

ORCID: https://orcid.org/0000-0002-4756-8977
} 
that such contradictions usually occur in the internal environment of the system and create a basis for exacerbation of inconsistencies, emergence of personal and industrial conflicts, not always light versions of them. Sometimes they lead to revolutionary changes in the top management of HEIs, heads of faculties, administrative departments, to choosing the alternative strategies for their development.

Experts distinguish conflicts due to the confrontation of social roles played by people (for example, formal and informal leaders), incomparability of the norms of behavior, life experience, values (the sources of which are the persons prone to academic dishonesty and scientific misconduct, supporters of authoritarianism); due to a conflict of expectations (let us say, several candidates for the vacant position of head of department, dean, rector);

c) to establish a rational subordination of subsystems (for example, the order for the managing and managed subsystems, functional units that take care of interconnected fragments of the educational process) and of the higher order system itself.

The second task is to make the management of HEI aware of the integrity of the object that came under control. This requires the following actions:

- to find out its nature ${ }^{1}$, to identify features and characteristics that indicate affiliation to the relations formed in the higher education system and enable the development of means to ensure economic security; - to outline the object's components, to provide their qualitative characteristics, to understand the mutual subordination and identify those key components that allow to reproduce properties inherent in the system; - to find the resources for ensuring security mobilized by HEI. These are both available sources and carrying out a thorough audit of costs, as some of them may be detrimental;

- to find out the structure of the whole system and the relationship between all its structural units, the circumstances accumulated in the organization and their interconnection;

- to depict the roles played by HEI. The first thing that comes to mind is the formation of professional competencies of educational services' customers and conducting researches. That is what on the surface. Meanwhile, we should not forget about the role to form a self-sufficient, socialized person with a high level of responsibility for the decisions he or she will make when holding some position in the future. The entrepreneurial role becomes increasingly important as HEIs are facing the need to provide themselves with everything necessary for operation;
- to check the history of formation and development of the system to understand its past and current state, the reasons for which we are at the present stage. This is regardless of whether the current events satisfy the organization or, conversely, give rise to concern; - finally, to predict the development path in the short and long term. This is about the use of non-traditional management technologies in the field of education, because the current tools have exhausted their limit and need to be replaced.

\section{Brief literature review}

Our colleagues are making a good progress in using a systemic approach to create software products for automation of decision-making for university management and control over the academic, scientific and administrative information flow in the environment (from the moment certain information emerges to its transfer to archives) (Prusty, Patnaik, 2017). This requires an accurate and unambiguous description of business processes that occur in HEI and the relations between them. The systemic approach is indispensable in the design and implementation of quality management systems for educational services.

The employees of the Faculty of the Sea Economics (FSE) of the Admiral Makarov National University of Shipbuilding (NUS) have been ensured of the validity of this statement in practice (Parsiak, Dybach, Parsiak, 2014); here, the quality management system is certified in accordance with the new version of the standard ISO 9001:2015 "Quality Management System - Requirements”. Apologists for the application of frugal management in HEI are attentive to the systemic approach. This is discussed, in particular, in the article (Höfer, Naeve, 2017). We are impressed by the scientists' views, as they are directly related to the problem that has been in the spotlight.

\section{The purpose of the paper}

On the basis of the consideration mentioned above, it has been hypothesized that the concept of "system" still needs to be clarified in the educational services, despite its widespread use in academic management. The sole concept of a systemic approach should be adapted accordingly, given the nature of the relationship between the participants in the educational process. The desire to solve the identified problems determines the purpose of this work.

On the way to it, the authors have used methods of generalization and systematization of primary information obtained during the performance

\footnotetext{
${ }^{1}$ It is not obvious at all especially in the new unfriendly environment. It is not limited to increasing competition in the market of educational services. Turbulence is increased by government, in particular, promises to reduce the government order. It seems that the official is happy with the mass academic migration and the prospects to provide diplomas to the natives of Ukraine at the expense of foreign taxpayers: Poland, Germany, Norway and other countries.
} 
monitoring of the Ukrainian centers of higher education, as well as data from the State Statistical Service.

\section{The essence and external attributes of the system}

In comparison with the past, nowadays, the range of use of the term "system" has expanded significantly. Under this concept, researchers and practical managers understand:

- the order caused by the arrangement of elements (groups, parts) provided in advance (Akademichnyi tlumachnyi slovnyk ukrainskoi movy, 2020);

- a set of elements interconnected so closely that they act in relation to the environment and other systems as a whole (Slovnyk osnovnykh filosofskykh terminiv, 2020); - a combination of organizations (enterprises, institutions, establishments) into an inseparable whole, a form of composition, organization of something (Morozov, Shkaraputa, 2020).

As we can see, in almost all cases, the sign of the system is the presence of components that contain the features of the whole and, at the same time, autonomously perceive their current and future state. Elements of the system can manifest themselves in certain way, experience the results of mutual activity and therefore, as defined, should respond to them adequately, particularly, move in the direction the system is interested in. For example, in 2013, the Faculty of Engineering and Economics of NUS was reorganized into the Faculty of the Sea Economics.

The decision of the Scientific Council taken after a long but rather intense discussion, met the public demands of the maritime economy's enterprises, their regional clusters and reflected the geoeconomic shifts taking place on the planet. All this can mean only one thing: the relationship between subsystems differs in mobility and flexibility. Theoretically, each of them should help in solving the problems facing the system.

However, at the same time, we have a number of examples of contradictions between the individual and the whole with some negative consequences for both subsystems and their totality as a whole. For example, the problem of ensuring the economic security of the educational institution cannot but worry the top management of the organization as well as each structural unit. But the admission campaigns of recent years have shown that some of them perform constructive initiative, while others are limited to completely unproductive concerns about reducing the birth rate in the country and increasing academic migration of young people. The consequences of this multi-vector position can be seen in Table 1 .

And what next? Along with the destruction of educational and professional programs, there can be liquidation of faculties, unification of departments with insignificant amount of students, reduction of teaching and support staff, deprivation of those who remained, decrease in wage supplement for high achievements in work, intensity of work, performance of especially important tasks. To sum up, it is unpleasant.

The system is able to preserve its identity in a changing and not always predictable environment, which constantly influences it. For example, the effectiveness of the formation of students' professional competencies significantly depends on the ability of applicants to absorb new knowledge and skills. This is more than relevant in the era of rapid development of technologies and methods of organization of production, which has been called the "fourth industrial revolution". The basis of a correct attitude to it should logically be shaped by teachers of colleges, lyceums, colleges and other

Table 1

The effect of inconsistency in the attitude of structural units to ensure the economic security of HEI (admission campaign of 2019-2020 academic year)*

\begin{tabular}{|l|c|c|}
\hline \multirow{2}{*}{\multicolumn{1}{|c|}{ Specialities }} & Amount of involved in receiving educational services, persons \\
\cline { 2 - 3 } & Bachelor's degree & Master's degree \\
\hline $\begin{array}{l}\text { Electrical Power Engineering, Electrical Engineering, } \\
\text { Electromechanics }\end{array}$ & 158 & 202 \\
\hline Shipbuilding & 191 & 92 \\
\hline River and Marine Transport & 152 & - \\
\hline Computer Sciences & 108 & 38 \\
\hline Law & 141 & 44 \\
\hline Applied Mechanics & 68 & 81 \\
\hline Management & 59 & 30 \\
\hline Physical culture and sports & 54 & 15 \\
\hline Philology & 39 & 51 \\
\hline Power Engineering & 38 & 29 \\
\hline Software Engineering & 32 & 18 \\
\hline Accounting and Taxation & 27 & 60 \\
\hline Heat Power Engineering & 16 & \\
\hline
\end{tabular}

${ }^{*}$ According to NUS Admission Committee 
institutions that perform the tasks assigned to them at previous educational levels.

But the teachers of the graduating departments of FSE, appealing to the accumulated professional experience, do not expect mercy from fate. Guided by the provisions of the created educational and scientific complexes, the developed integrated curricula, the concluded agreements on cooperation, they carry out lessons of economics, financial literacy in schools ${ }^{2}$, give lectures, start thematic contests, academic competitions, tournaments, quests. They also participate in extracurricular activities as coaches, mentors, moderators, and guides.

In another way, HEI positions itself in relations with other stakeholders, as folows:

- competitors with whom they intersect through the provision of similar educational services in common market segments. Signs of intensifying competition are numerous examples of the use of marketing tools by marketing management: advertising, PR, offers of original educational products, forms of communication between teachers and students using modern educational technologies and global information networks;

- with enterprises-, institutions- and organizationscustomers of specialists of relevant professions, including coordinated dual education programs, which are becoming increasingly popular as they prove their effectiveness in practice. While studying at the university, students acquire professional skills in future or similar workplaces, significantly reducing the time to adapt to relevant business processes. Individuals of this type have no problems in the labor market. Moreover, there is a real struggle between the HR managers for the right to conclude a contract with them;

- with state bodies that take care of the implementation of policy in the field of education, carry out accreditation, licensing of educational programs, monitor compliance with educational standards, as well as determine the scope of public procurement. Usually, the Ministry of Education and Science of Ukraine and the National Agency for Higher Education Quality Assurance are mentioned in this context. Meanwhile, we note that part of HEIs in our country is subordinated to other bodies of state executive power with the following number of students, available in Figure 1 (Vyshcha osvita, 2019).

\section{Internal organization of HEI system}

Another constitutive attribute of the system is its inherent structure. By default, it arranges the internal organization of the system, streamlines the interaction of all its components. The results of multiannual observations of the operation of public and private higher education institutions, conducted by the authors, allowed to make the following conclusions:

1 . If the system is unstructured or designed with fundamental flaws (for example, without taking into account the amount of students and teachers, with an exaggerated control over the activities of basic educational units instead of concentrating on monitoring changes and developing strategies to strengthen economic security), there is no system as a whole. Characteristics of the most important academic units of HEI are available in Table 2 (Zakon Ukrainy, 2020).

2. The management should compose the structure in such a way that the interests of the involved personnel at each stratum of the higher education institution are in harmony with its vision and mission. Let us say that for the vast majority of HEIs, it is becoming increasingly important to achieve the best ratio between the quantity and quality of teaching, support and administrative personnel, especially given the growing shortage of

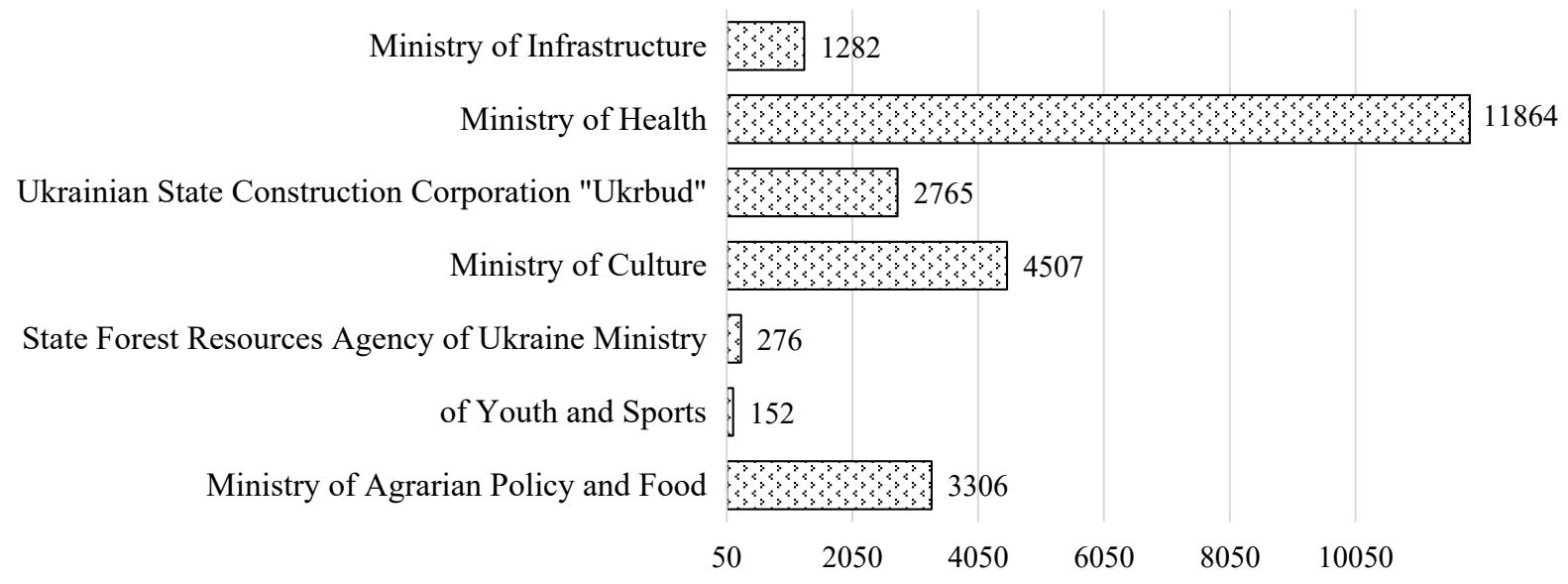

Figure 1. Amount of students at the beginning of the 2017-2018 academic year, in the field of management of ministries (departments) in which HEIs are located, persons

\footnotetext{
${ }^{2}$ When Hrynevych L. was the Minister of Education and Science of Ukraine, the corresponding course was introduced as a mandatory part of the school curriculum. Few people were interested in whether the teachers were ready for this.
} 
Table 2

Key elements of higher education institution as a system*

\begin{tabular}{|l|l|}
\hline \multicolumn{1}{|c|}{ Title } & \multicolumn{1}{c|}{ Function } \\
\hline $\begin{array}{l}\text { Educational and } \\
\text { Scientific Institute }\end{array}$ & $\begin{array}{l}\text { A structural unit of a university, academy, institute that consolidates the relevant departments, laboratories, scientific } \\
\text { research centers and experimental laboratories that conduct educational activities and research }\end{array}$ \\
\hline Faculty & $\begin{array}{l}\text { A structural unit of a higher education institution that consolidates minimum three departments (laboratories), which } \\
\text { together provide training of at least 200 full-time graduates in state and municipal higher education institutions }\end{array}$ \\
\hline Department & $\begin{array}{l}\text { A general structural unit of higher education institution of state (communal) form of ownership (its branches, } \\
\text { institutes, faculties), which conducts educational, methodological (scientific) activity in a certain speciality or } \\
\text { interdisciplinary group of specialities, which includes at least five academic workers for whom the department is the } \\
\text { main place of work, and at least three of whom have a scientific or academic (honorary) title }\end{array}$ \\
\hline
\end{tabular}

*Explanation: In addition to faculties and departments of HEI, the same article of the Law includes libraries, i.e. the place where students and teachers get access to paper and electronic media of specialized information.

funds due to the collapse of the national market of higher education services, the consequences of public administration decentralization with a corresponding redistribution of funds between the budgets of the country and local communities. It is considered that they have a better understanding of the personnel needs in the regions and, therefore, should take care of ordering educational services, particularly in universities.

Most rectorates are forced or deliberately thinking about reengineering the educational process, seeking to get rid of units that burden the expenditure side of the budget. For example, in V.O. Sukhomlynskyi Mykolaiv National University in the 2019-2020 academic year, students in tuition-paying and tuition-free bases were divided into different groups, for which they differentiated the amount of class exercises depending on funds received from the relevant sources. Since the state, on average, allocated more for education than the amount, for which HEI undertook to provide education services to students at the expense of individuals and legal entities ${ }^{3}$, then it was decided to "save" in such a creative way. Someone had no problem with this transformation. Most of the applicants who hoped to receive good education began to oppose the innovation, and with the rest of them went to look for a better fate in the neighbouring HEIs.

Basically, it is difficult to disagree with the desire to respond rationally to the latest threats and challenges (certainly not in the barbaric ways). At the same time, we consider it our duty to pay attention to the need for a thorough analysis of reserves of the administrative services, which often have fairly surplus personnel with the unacceptably blurred job responsibilities. Using phrases from fairytales, some "officials" are required to "go I know not whither and fetch I know not what". And, it is not surprisingly, but they go and fetch something during the working day for years, although everyone is completely indifferent to them.

They do not fetch it to the same basket, which, unfortunately, also happens. In 2018, the National
Police in Zaporizhzhia oblast exposed a criminal group of employees of state HEI and a private enterprise who, according to forged official documents, accepted foreigners "for training". They visited Ukraine, but with the sole purpose of settling accounts with those who abused their official position in a timely manner. While executing searches, 110 thousand USD and 70 thousand EUR were seized in addition to the evidence of criminal activity (Na Zaporizhzhi, 2018);

3. If we resort to a broad interpretation of the essence of the structure, it turns out that it ca be used to characterize the connections required for the system to cope with the solution of the enormous number of problems that face it on the way to the defined goal. Without these connections, it would not be able to appear, function, or, moreover, take care of its safety.

\section{Organizational structure of HEI}

Generalizing the experience of using a systemic approach, academic theorists have opened the relationship discovered to practice managers, the varieties of which are summarized in Figure 2 and Table 3. Analyzing the above data, we found a correlation between what it depicts and the key business processes that make up the operation of higher education institutions. We do not consider it a mistake to use the category of "business process" in this context, as today's HEIs are increasingly manifesting themselves in two images: on the one hand, a trustee of educational service recepients, and, on the other hand, a market operator concerned with increasing revenues and economic independence.

In this case, the business process is considered as a sequence of ordered actions of the personnel, so that in result, students receive the expected profession. The peculiarities of each of the business processes determine the content of strategies and measures to ensure the economic security of HEI. We took the liberty to cover the process map of a higher education institution, creating a text interpretation of its structural model:

\footnotetext{
${ }^{3}$ This is not a charity, but a marketing tool aimed at increasing the competitiveness of the market offer compared to other universities represented in the regional segment. Households, especially those in rural areas, respond instantly to such a lure, trying to provide education to their children and grandchildren.
} 




Figure 2. Generalized model of the organizational structure of HEI

Table 3

Varieties of system connections and their characteristics

\begin{tabular}{|l|l|l|}
\hline Title & \multicolumn{1}{|c|}{ Characteristics } & \multicolumn{1}{c|}{ Example } \\
\hline $\begin{array}{l}\text { Between the } \\
\text { systems' elements }\end{array}$ & $\begin{array}{l}\text { Determine the degree of interaction of the } \\
\text { system's elements, which ultimately affects the } \\
\text { qualitative features of its operation. It has an effect } \\
\text { on the efficiency of system management and, as a } \\
\text { consequence, the performance of the administration }\end{array}$ & $\begin{array}{l}\text { Connections between the Supervisory Board and the } \\
\text { administration of HEI; the Academic Council and the Rectorate; } \\
\text { the Rectorate and the heads of structural divisions; the Dean's } \\
\text { Office (Directorate) and the searching staff and support staff, } \\
\text { united in departments, research laboratories, institutes, faculties }\end{array}$ \\
\hline System-wide & $\begin{array}{l}\text { Preserve the integrity, maintain the system's } \\
\text { integrative properties regardless of the quantitative } \\
\text { and qualitative composition of its elements. Play a } \\
\text { decisive role in creating a synergistic effect }\end{array}$ & $\begin{array}{l}\text { Subordination of all basic educational subdivisions, management } \\
\text { bodies and support services, which are a part of HEI, to the } \\
\text { general purpose and the chosen strategy of movement to it } \\
\text { through reflection of the corresponding tasks in individual plans } \\
\text { of teachers, current and perspective tasks to other personnel }\end{array}$ \\
\hline Reverse & $\begin{array}{l}\text { Come as a signal of the system's response to certain } \\
\text { exogenous and endogenous changes, events and } \\
\text { disturbances that occur in this regard at the input of } \\
\text { the system or its individual elements }\end{array}$ & $\begin{array}{l}\text { Reorientation of preparatory centers to provide services for the } \\
\text { preparation of applicants for preliminary examinations to train } \\
\text { them for the successful completion of external independent } \\
\text { evaluation (EIE) }\end{array}$ \\
\hline
\end{tabular}

1. The process of operational activities related to the development and implementation of educational programs. They gather intellectual products, through their implementation HEIs receive income, which is the key to their economic stability and independence. It should be recalled that the Law of Ukraine "On Higher Education" also defines the educational program as a system of educational components at the appropriate level of higher education within the speciality, which determine the requirements for the educational level of persons able to start training in this program, the list of disciplines and their logical sequence, the number of credits for European Credit Transfer and Accumulation
System necessary for the implementation of this program, as well as the expected training results that must be mastered by the applicant of the appropriate degree of higher education (Zakon Ukrainy, 2020);

Operational activities are aimed at creating appropriate conditions for the acquisition of professional competencies required for further work according to the chosen speciality by all the persons who have the desire, vocation and a satisfactory level of prior education. It consists of a number of business functions:

- enrollment of entrants in accordance with the approved conditions and rules of admission to higher education institutions; 
- formation of knowledge and skills according to the educational programs of each level of higher education and specialities in demand;

- current management of educational activities (control over the observance of academic discipline, academic integrity, acquired knowledge and skills).

2. The process of research and development in HEI. This means creating and improving the comfortable academic environment, developing new and modernizing existing educational programs that meet the demands of the real and financial sectors of the economy of the country or region. The modern reform of operational activities in the context of the fourth industrial revolution is of particular importance. It is known to differ from the previous ones by a broad appeal to the services of artificial intelligence and the use of the latest information technologies. With regard to educational activities, this means, in particular: digitalization of education (e-learning technology), which provides access to an array of educational resources of leading universities (audiovisual online courses, online exams), libraries (electronic textbooks, abstracts), research centers represented on the World Wide Web, involvement to participate in distributed research and academic groups. The first of them create the prospects for mobilizing the collective mind to improve the professional behavior (actions) of teachers and leaders of HEI to evolve their results. In educational groups, students from different universities (sometimes in other countries or even on continents) arrange discussions on current issues or listen to lectures by representatives of different scientific schools providing further discussion of the information, receptivity and effectiveness of the proposed didactic methods;

- personalization of education (as opposed to unified curricula and standardized approaches to teaching disciplines) with the construction of an individual educational trajectory. Acquisition of skills to deepen knowledge throughout life (as a response to the fast updating of equipment and technology), taking into account the requirements and demands generated in industrial labor markets by employers. The latter are looking for self-sufficient persons among the candidates for vacant positions who are able to identify current problems, form effective professional teams to solve them, properly distribute responsibilities and coordinate the colleagues' activities, evaluate and motivate participants.

Personalization technology is based on the online learning materials prepared by HEI, students search for additional resources and teachers control the progress (learning rate, cognitive capabilities) in real time providing appropriate services to anyone who needs it, on individual requests or in small groups. It is especially useful for people who combine learning with work (and there are more and more of them), those with special needs, as well as experienced professionals in need of advanced training;

- project approach to the formation of the content and technology of higher education in order to create a layer of professionals who realize their potential as knowledge and skills acquired during learning, to generate innovations in industrial and social spheres (depending on the place of work), ensuring their continuous and gradual progress. For this purpose, students are involved in solving an acute problem that has arisen in the real life of the organization. At the same time, the necessary conditions are created to demonstrate personal abilities to understand the situation and choose effective tools to achieve the goal, visualization of the results obtained through graphs, diagrams, mathematical or physical models, schemes, etc.;

- a combination of formal (within the scope of licensing and accreditation of educational programs, providing a degree, diploma, certificate, recognized by the state) and non-formal education. The latter takes place outside the time regulations established by the schedule of the educational process, the approved schedule of classes and the academic spaces of classrooms, methodics offices and laboratories of universities.

The key characteristics of non-formal education are its voluntariness, independent decision-making by a person who must be capable to study until retirement. An example is the meetings of the Successful Alumni Club of FSE, where there are meetings of current and former students who have achieved great success in their own business, delegated management or have extraordinary professional up rises in their positions. In a relaxed, friendly circle, the participants exchange unique knowledge and life experience, which significantly expands the understanding of young people about career planning in the future.

Excursions to enterprises and organizations, stories of their managers and leading employees about the organization of production, methods of personnel motivation, implementation of innovative projects, technologies of investment attraction, etc. are also useful. There are also courses, workshops, seminars, other forms of education that enrich students with new values, attitudes, knowledge and skills.

3. The process of administration (planning, organization, control, analysis, motivation) of the staff of HEI as a holistic system. It consists of the implementation of accordingly approved procedures, the appointment or election of officials (rector, vicerectors, deans) and administrating bodies (staff meetings, the academic council, rector, administrative departments, deans).

All of them are organized and subordinated in accordance with the legislation, the charter of HEI, the provisions on structural units, job descriptions of employees, contracts concluded with them (in terms of responsibilities assigned to performance). 
The teaching and technical staff must have adequate moral and material incentives in order to perform their duties to add value to the educational service in its creation chain.

We consider it necessary to emphasize that the approaches to the management of HEI in our time are different from the previously accepted. The reason is a radical change in the environment where educational activities take place. Stability (funding, number of entrants, hourly rates of teachers, etc.) is a thing of the past. Therefore, we are convinced that strategic management of universities becomes relevant. In short, its content is a task for the rector's team to find the answers to a number of key questions (Figure 3).

Obviously, these issues are so important and complex that it would be reckless to rely on the vision of top management alone. Strategy development is a joint task of the administration, the heads of departments (they understand the characteristics of market segments that serve their teams) and each teacher who perceives HEI as his or her second home.

It often happens that many of them have received higher education, degrees and titles in this HEI, have devoted the best years of their lives to the development and implementation of scientific and academic projects. That is why the appeal to their experience and professional knowledge is able to encourage constructive initiative, create a synergy of collective vision of the future, accurately outline the vector of movement in an unknown, poorly predicted environment.

4. The process of providing and supporting academic and administrative operation. Its components include: - procurement of resources necessary for the operational activities of HEI at prices comparable to the budget potential and quality requirements;

- improvement of the university infrastructure (financial, legal, administrative), which supports the reputation of $\mathrm{HEI}$, contributes to improve its image in the minds of the public, customers of educational services, the business community;

- economic activity (maintenance of real estate, including their capital construction and reconstruction, provision of transport services, provision of all types of communications, safety and labor protection).

The processes in question and the sub-processes that make it up are important. For example, at Odessa National Medical University in 2018, goods and services were purchased for 22.5 million $\mathrm{UAH}$; it is $19 \%$ of the total current expenditures. Another amount of 152.5 thousand UAH was spent on the acquisition of fixed assets (Koshtorys vytrat, 2018). It is a great deal of money. Therefore, business management depends on economically feasible use of resources purchased by the organization.

\section{Conclusions}

It is unlikely that there will be an impartial person who will take the courage to deny the urgency of the problem of ensuring the economic security of higher education institutions in modern realities of Ukraine. It is obvious that the American model is dominating in our area, according to which the finance burden of the initiated programs is on their initiators - higher education institutions. We are not inclined to assess the choice of government, especially since, under the circumstances, more than one generation of state leaders is behind the relevant political decisions. We believe that the search for ways and means to mobilize internal reserves to ensure the stability of the organization in the market of educational services is more constructive.

Along with academic, economic security should be the focus of university management. This statement is increasingly realized by the leaders of HEIs, as well as the heads of structural units, to which, as a rule, the responsibility for non-receipt of funds are delegated "from the top". In part, this treatment is fair. It is the departments and faculties that determine the attractiveness and quality of educational and professional programs - the main product offered to the market.

We consider the hypothesis about the importance of laying a systemic approach in the basis of decisions to ensure the economic security of HEI to be proved.

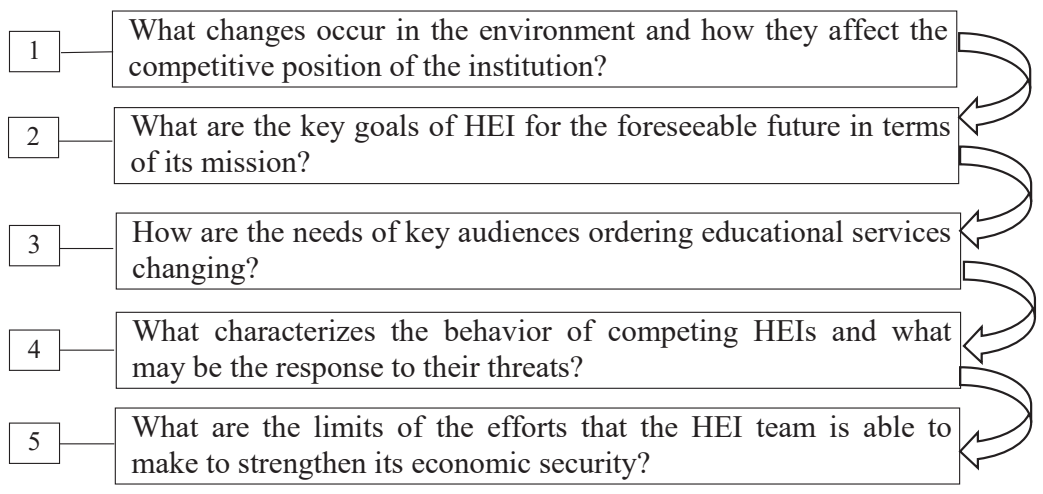

Figure 3. Key issues of HEI's strategic management 
Behind the outer shell of the organization, which we are used to seeing in business, there are a number of subsystems. Each of them has a unique purpose, solves problems that are typical to it. Universal tools for the impact of management on staff will not work. The professor of the department differs from the technical worker in all parameters (job responsibilities, "production" technologies). These features must be taken into account, because everyone's contribution to the common cause is important.
The educational institution is obliged to respond to changes that occur from the outside quickly and effectively, as it is part of the country's higher education system and an integral part of the economic system. Appropriate educational products are launched at its request and for meeting its needs. Non-compliance with market expectations is a threat to the economic danger of HEI. We hope that the considerations set out in this regard will be useful to our colleagues.

\section{References:}

Akademichnyi tlumachnyi slovnyk ukrainskoi movy (2020). Available at: http://sum.in.ua/s/systema (in Ukrainian)

Dybach, I. L., Zhukova, O. Iu., Parsiak, V. N. et al. (2019). Universytetskyi menedzhment: pidgruntia zaprovadzhennia. Monohrafichna seriia. Kherson: Vydavnychyi dim «Helvetyka». (in Ukrainian)

Höfer, S., \& Naeve, J. (2017). The Application of Lean Management in Higher Education. International Journal of Contemporary Management, issue 16(4). Available at: http://www.ejournals.eu/ijcm/2017/Numer-16(4)/ art/11328/

Koshtorys vytrat. Odeskyi natsionalnyi medychnyi universytet (2017). Available at: https://onmedu.edu.ua/ wp-content/uploads/2017/06/Koshtoris-2018r.-2301170.pdf (in Ukrainian)

Morozov, S. M., \& Shkaraputa, L. M. (2000). Slovnyk inshomovnykh sliv. Kyiv: Naukova dumka. (in Ukrainian)

$\mathrm{Na}$ Zaporizhzhi posadovtsi VNZ orhanizuvaly fiktyvne navchannia inozemtsiv (2018). Available at: https://prm.ua/na-zaporizhzhi-posadovtsi-vnz-organizuvali-fiktivne-navchannya-inozemtsiv/ (in Ukrainian)

Parsiak, V. N., \& Drahomyrova, I. M. (2010). Transformatsiia diialnosti operatoriv rynku osvitnikh posluh na zasadakh korporatyvnoho menedzhmentu. Mykolaiv: Vydavnytstvo Torubara O.S. (in Ukrainian)

Parsiak, V. N., Dybach, I. L., \& Parsiak, K. V. (2014). Upravlinnia yakistiu osvitnikh posluh. Mykolaiv: Vydavnytstvo «Talisman». (in Ukrainian)

Prusty, S., Patnaik, R. et al. (2017). University management system using model-view-controller. Available at: https://www.researchgate.net/publication/322099765_university_management_system_using_model-viewcontroller_mvc_1

Slovnyk osnovnykh filosofskykh terminiv (2020). Available at: http://library.nlu.edu.ua/POLN_TEXT/ KOMPLEKS/KURS_1/kurs/5/109.htm (in Ukrainian)

Vyshcha osvita v Ukraini u 2017 r. (2018). Statystychnyi zbirnyk (2018). Derzhavna sluzhba statystyky Ukrainy. (in Ukrainian)

Zakon Ukrainy pro vyshchu osvitu (2020). Available at: http://zakon.rada.gov.ua/laws/show/1556-18 (in Ukrainian) 